\title{
超長寿命疲労試験データの評価法に関する研究†
}

\author{
座 古 勝* 倉 敷 哲 生* 花 木 聡**

\section{On Evaluation Method of the Data for Super-Long Life Fatigue Property}

by

\author{
Masaru ZaKo ${ }^{*}$, Tetsusei KurashiKI ${ }^{*}$ and Satoshi HanaKI ${ }^{* *}$
}

In this paper, a statistical method for the evaluation of the data related to the super-long life fatigue region is proposed. According to a research paper published by the "Research Group on the Statistical Aspects of Material Strength", failures are classified into two modes. That is, the failures due to cracks originated on the surface and those due to crack resulting from internal material defects. Therefore, to evaluate the fatigue properties in this region, the experimental data should be separated according to these two modes.

To decide the optimum separation between these two modes, we make a first separation based on the number of cycles. Then we draw the two fatigue strength plots on probability papers, and we calculate the two coefficients of correlation. The separation line is shifted and the previous procedure is repeated. The optimum separation is the one for which the sum of these coefficients reaches its maximum.

Using this proposed method, a computational system to decide the $S$ - $N$ curve to be used in the design has been developed. To validate the proposed method, we applied the computational system to the fatigue test data of different materials. The agreement of this separation with that of obtained by SEM observation allow us to judge positively our method and to confirm the accuracy of the obtained S-N curves.

Key words : Super long life fatigue, Statistical method, $S-N$ curve, Design margin

\section{1 緒}

一般に材料の疲労試験結果は，ばらつきを有する場合 が多く，S-N曲線の決定にはこのばらつきを考慮する必 要がある。我々は以前，耐久限度を考慮した $S-N$ 曲線の 決定法を提案した. ${ }^{1}$ 提案手法では適用範井を長寿命域の みに限定し，これらの領域において各寿命での疲労強度 のばらつきが一定とした仮定を基に $S-N$ 線罒を決定した。

一方，高強度鋼や表面処理材に打いて $S-N$ 曲線の水平 部（耐久限度）が現れた後, 繰り返し数 $10^{7}$ を越える超 長寿命域において再び降下する超長寿命の特性が報告さ

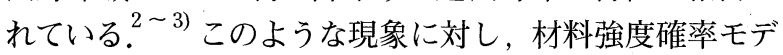
ル研究会では高炭素ク口ム軸受け鋼 SUJ2 に関する大規 模な疲労試験を行い, これらの現象は, 材料表面からの き裂進展と内部欠陥からのき裂進展による破壊試験片が 混在することに起因することを報告している. に異なるモードにより破壊したデータが混在する場合， そのばらつきを単一分布で評価する事は非常に困難とな る。すなわち，二種以上の異なる母集団から得られたデ 一タを一つの分布に当てはめることになるため，充分な 分布適合度を得ることは難しい，そこで本報では，疲労 試験結果を各破壊モードに対するデータに分離し， S-N 線困を決定する手法を提案する。 また，この手法を用い て構築した設計基準決定法について記述する。

$$
2 \text { 仮定 }
$$

一般に, $S-N$ 曲線は縦軸（= 応力レベル）を真数また
は対数とした場合，直線で近似されることが知られてい る.また, 疲労寿命は対数正規分布あるいはワイブル分 布に従い，疲労強度分布は正規分布，対数正規分布，ワ イブル分布のいずれかに従うことが報告されている.5) 以 上の実験的事実を考慮し，提案手法においては $S-N$ 線図 を決定するために次に示す仮定を用いるものとする。

(1) $S-N$ 線困は長寿命域と超長寿命域の二つの部分か らなる。また，これらの領域はある寿命において分離さ れるものとする.

(2) 各領域において， $S-N$ 線図は傾斜部と水平部また は傾斜部のみからなる。また，傾斜部において縦軸が対 数または真数のいずれかの場合に打いて直線となる.

(3) 各領域内に打ける疲労強度分布のばらつきは寿命 によらず一定である。

以上の仮定に基づいた $S-N$ 線図の概略を Fig. 1 に 示す.

このとき, 各領域において疲労寿命 $N_{f}$ と応力レベル $\sigma$ の間には次の関係が成り立つ6)

i）両軸が対数の場合

$$
\begin{array}{ll}
\log \sigma+m_{0} \log N_{f}=\log D_{0} & \left(N_{f} \leq N_{c}\right) \\
\sigma=\sigma_{c} & \left(N_{f}>N_{c}\right)
\end{array}
$$

ii）横軸が対数, 縦軸が真数の場合

$$
\begin{array}{ll}
\sigma+m_{0} \log N_{f}=D_{0} & \left(N_{f} \leq N_{c}\right) \\
\sigma=\sigma_{c} & \left(N_{f}>N_{c}\right)
\end{array}
$$

$\dagger \quad$ 原稿受理 平成 12 年 4 月 10 日 Received Apr. 10, 2000

* 正会員 大阪大学大学院工学研究科生産科学専攻 †565-0871 吹田市山田丘, Dept. of Manufacturing Science Eng., Osaka Univ., Yamadaoka, Suita, $565-0871$

** 正会員 大阪大学大学院 $\overline{\mathrm{T}} 565-0871$ 吹田市山田丘, Graduate Student, Osaka Univ., Yamadaoka, Suita, 565-0871 


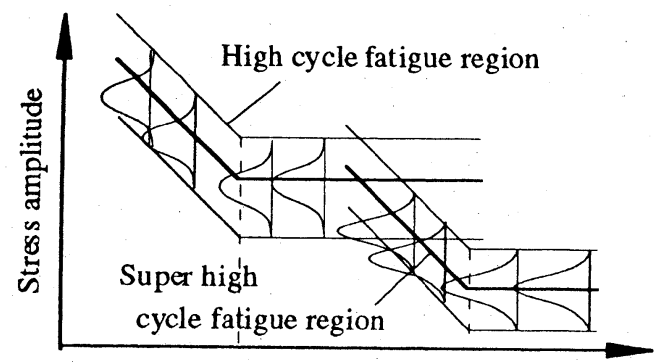

Number of cycles to failure

Fig. 1. Scheme of $S-N$ diagram.

ここで, $D_{0}$ は静的強度に対する強度定数であり， $m_{0}$ は対数寿命に対する応力減少量である。.また， $N_{c}$ および $\sigma_{c}$ は限界繰返し数および耐久限度応力レベルである. 各 分布形状と $S-N$ 曲線の定式の関係は Table I に示す組み 合わせを考慮するものとする.

ここで, 各領域内における分布形状が一定であるとい う仮定に基づき, 換算応力を定義する. 換算応力は Fig. 2 に示すように, 各寿命に対する疲労強度を限界繰返し 数における疲労強度に換算したものである. 換算寿命 $\sigma^{*}$ は次式により求められる.

i）両軸が対数の場合

$$
\begin{array}{ll}
\sigma^{*}=\sigma \times\left(\frac{N_{f}}{N_{c}}\right)^{m_{0}} & \left(N_{f} \leq N_{c}\right) \\
\sigma^{*}=\sigma & \left(N_{f}>N_{c}\right)
\end{array}
$$

ii) 横軸が対数, 縦軸が真数の場合

$$
\begin{array}{ll}
\sigma^{*}=\sigma-m_{0}\left(\log N_{c}-\log N_{f}\right) & \left(N_{f} \leq N_{c}\right) \\
\sigma^{*}=\sigma_{c} & \left(N_{f}>N_{c}\right)
\end{array}
$$

Table I. Relation between the formulation of the $S-N$ curve and the types of distribution.

\begin{tabular}{|c|c|c|}
\hline Formulation of S-N curve & $\begin{array}{c}\text { Type of } \\
\text { distribution } \\
\text { for fatigue } \\
\text { life }\end{array}$ & $\begin{array}{c}\text { Type of } \\
\text { distribution } \\
\text { for fatigue } \\
\text { strength }\end{array}$ \\
\hline $\log \sigma+m_{0} \log N_{f}=\log D_{0}$ & Log-normal & Log-normal \\
\hline$\sigma+m_{0} \log N_{f}=D_{0}$ & Log-normal & Normal \\
\hline $\log \sigma+m_{0} \log N_{f}=\log D_{0}$ & Weibull & Weibull \\
\hline
\end{tabular}

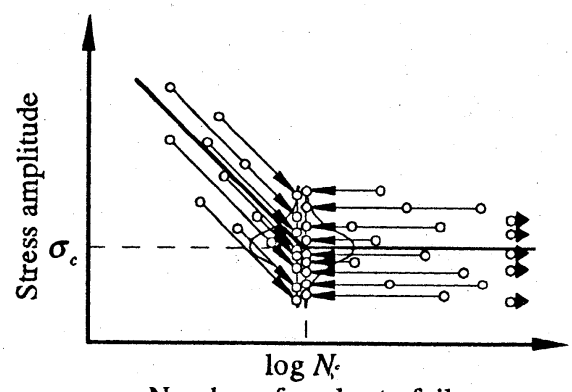

Number of cycles to failure

Fig. 2. Scheme of normalized fatigue strength.

\section{$3 \cdot 1$ 分離アルゴリズム}

\section{3 提 案 手 法}

異なるモードにより破壊したデータが混在する場合， これらを破壊モード毎に分離した上で評価する必要があ る。しかし，一般に存在する疲労試験結果のうち SEM 写真等により破壊モードが確認できる例は非常に少ない. そこで本研究においては以下のような手法を提案する。

材料の疲労特性において破壊モードが単一である場合， 疲労強度分布は寿命によらずほぼ一定となることが報告 されている．そこで分離する寿命 $N_{s}$ を変化させながら各 領域における疲労強度データに分布をあてはめ，その適 合度により長寿命域と超長寿命域を分離する。まず， Fig. 3 に示すようにある寿命 $N_{s}$ を仮定し，この $N_{s}$ にお いて全データを 2 つ領域に分離する。次に，各領域に おいて次項に示す手順により $S-N$ 曲線および疲労強度分 布の当てはめを行う。なお，疲労強度分布は前述した換 算応力を確率紙にプロットすることにより推定する。ま た，最小二乗法を用いて直線回帰を行う際に得られる相 関係数を分布適合度とする.

以上の操作を分離する寿命 $N_{s}$ を変化させつつ繰り返 し行い，これらの中で，両領域の分布適合度の和が最大 となる寿命を最終的に両領域の分離点とする。

なお，材料や試験条件によっては長寿命域と超長寿命 域が寿命方向に明確に分離されず，各領域における寿命 分布が重なって現れる例も報告されている。このような 場合，提案手法のように寿命データのみから両領域を分 離することは不可能であり，破面解析等でモードを確認 して分離する必要がある。

\section{$3 \cdot 2$ 各領域における $S-N$ 曲線の決定法}

限界繰返し数に打ける傾斜部と水平部の疲労強度分布 の同一性を考慮し，これらの比較により耐久限度を決定 する.すなわち，傾斜部と水平部を分離する寿命 $N_{c 1}$ お よび $N_{c 2}$ を微小に変化させつつ傾斜部と水平部の換算応 力の分布を比較し，これらのうち傾斜部と水平部の分布 が最も一致する寿命を限界繰返し数とし，その応力レべ ルを決定する。

長寿命域を例に具体的な手順を以下に示す.Fig. 4 に 示すように，まず任意の寿命 $N_{c 1}$ において全データをこ の $N_{c 1}$ 以前と以後のデータに分離し，それぞれを傾斜部 と水平部とする。次に, この傾斜部データに対し最小二

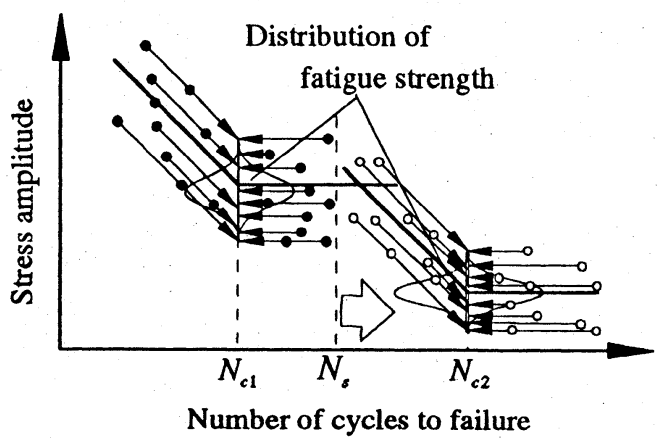

Fig. 3. Scheme of the separation procedure. 
乗法を用いて直線回帰を行ない, 強度定数 $D_{0}$ および強 度劣化指数 $m_{0}$ を計算する. また, 傾斜部における寿命 $N_{c 1}$ に対する応力レベル $\sigma_{c 1}$ を耐久限度と仮定する．これ らのパラメータを用い, 傾斜部と水平部の各データに対 する換算応力を計算する．これらの換算応力により傾斜 部と水平部の疲労強度分布を求め, 両者の比較を行なう.

分布の比較は確率紙を用いて行なう.Fig. 5 に示すよ うに, 各々の分布の確率紙に傾斜部および水平部の換算
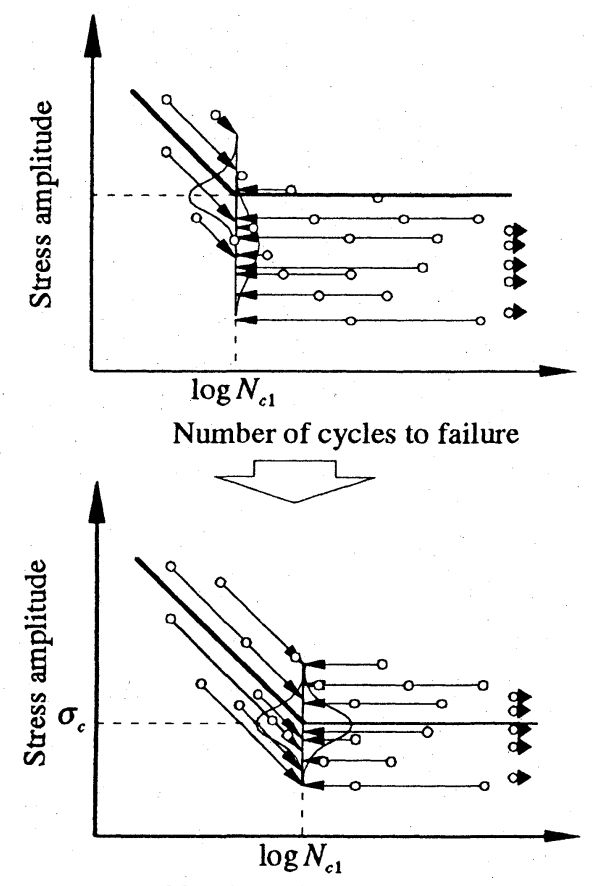

Number of cycles to failure

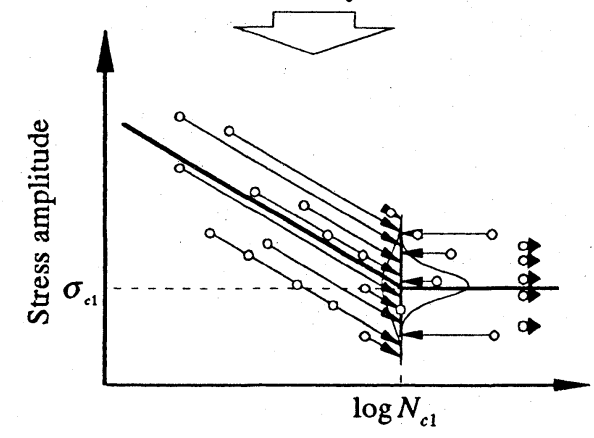

Number of cycles to failure

Fig. 4. Scheme of the method to decide $S-N$ curve.

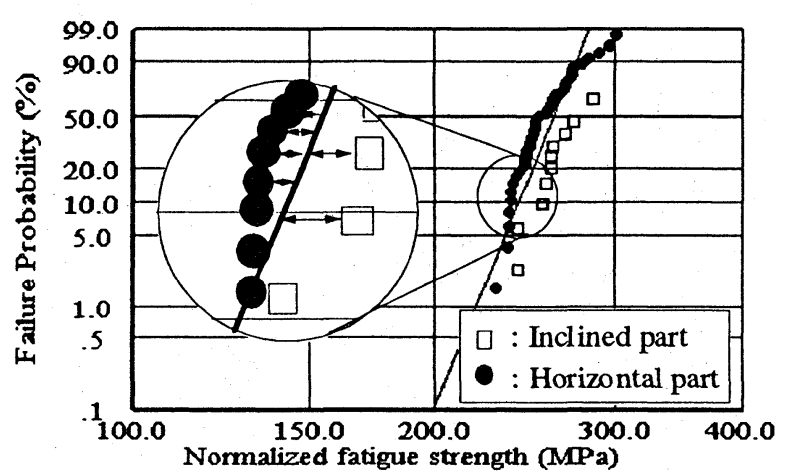

Fig. 5. Scheme comparison of distribution by probability paper.
応力をそれ六れプロットする，次いで，全プロット点に 対し最小二乗法を用いて直線もしくは曲線をあてはめ, この線と各プロット点との応力に関する残差総和を計算 する.ここで, 先の 3 種類の分布においてどの分布を適 用するかは, 直線もしくは曲線をあてはめる際の相関係 数 (=分布適合度 $)$ により決定する.

以上の手順を寿命 $N_{c 1}$ を变化させつつ繰り返し行ない, これらの中で残差総和が最小となる寿命 $N_{c 1}$ を限界繰返 し数とし, その応力レベルを決定する. 寿命 $N_{c t}$ が決定 すると同時に疲労強度の分布形状が決定され, Table I より $S-N$ 線困の定式（縦軸を対数とするか真数とするか） が決定される．超長寿命域においても同様の手法を用い て，分離寿命 $N_{c 2}$ を決定する。

なお，傾斜部と水平部の分布が一致する寿命が発見で きない場合は解析範囲内において耐久限度が決定出来な い.このような場合は耐久限度を決定せず, 全体を傾斜 部と見なして換算応力の分布を求め, Table Iの関係に 従って $S-N$ 線図を決定する。

\section{4 設計基準の決定}

前章において得られた $S-N$ 曲線および疲労強度分布を 用いることにより，任意の設計目標（破壊確率 $P a$ およ び信頼水準 1- $\gamma$ ) に対する設計基準の決定が可能となる. Fig. 6 にその概念困を示す.

設計応力レベル $\sigma_{d}$ は Fig. 7 に示す換算応力の分布に おいて斜線の部分の面積が $1-\gamma$ 信頼水準で $P a$ 以下とな るように決定される. ${ }^{6)}$ ここで，下側の分布は破壊確率 $P a$ に対する設計応力レべルの分布を示す．設計用 $S-N$ 曲線 は長寿命域と超長寿命域のそれぞれの領域において決定

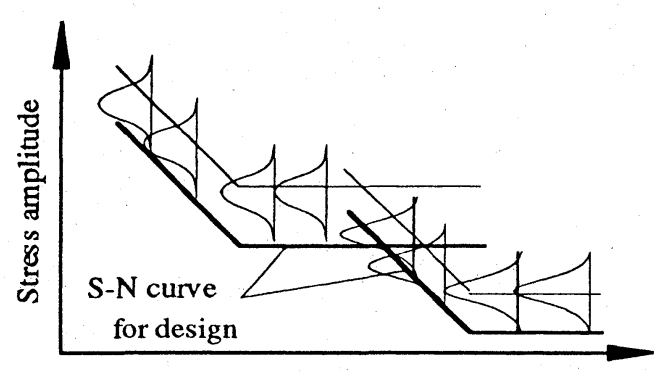

Number of cycles to failure

Fig. 6. Scheme of $S-N$ curve for design.

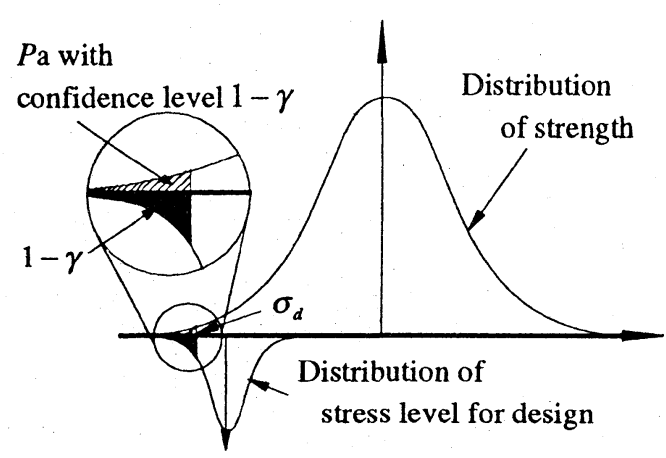

Fig. 7. The distribution of normalized fatigue strength with a confidence level. 
される．設計用 $S-N$ 線図はFig. 6 に示すようにそれぞれ の領域から得られた設計線図の安全側を適用するものと する。

\section{5 解 析 例}

構築したシステムを実疲労試験結果に適用した例を示 す．材料強度確率モデル研究会により編集された MSDRD (Materials Strength Database for Reliability Design of Machines and Stractures) ${ }^{7)}$ に収録される機械構造用炭 素鋼 S45C の焼き戻し材の疲労試験結果に対し得られた $S-N$ 線困を Fig. 8 に示す. Fig. 8 より得られた $S-N$ 線困 は実験結果をよく表現していると考える.

また，各領域における換算応力の確率紙へのプロット を Fig. 9 に示す. 解析の結果, 超長寿命域では耐久限度

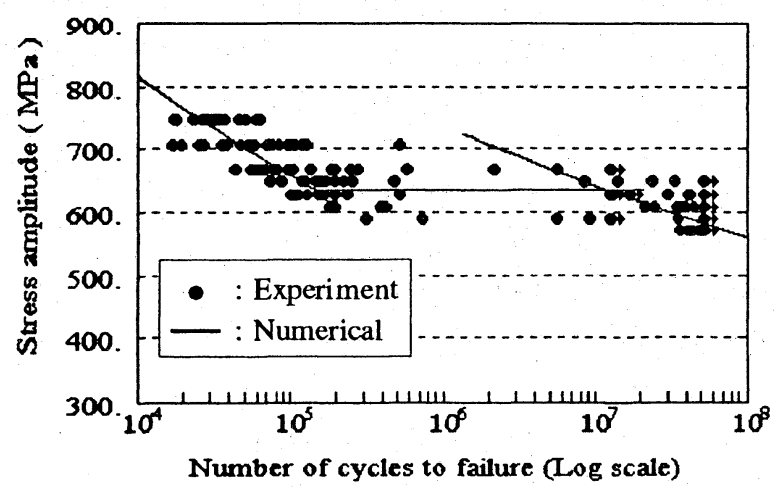

Fig. 8. Numerical result of the $S-N$ curve for S45C (MSDRD : 0070200. MTL).

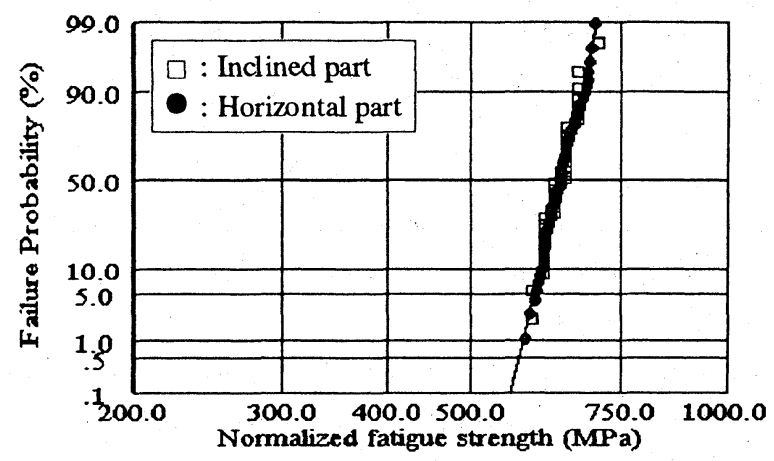

(a) High cycle fatigue region

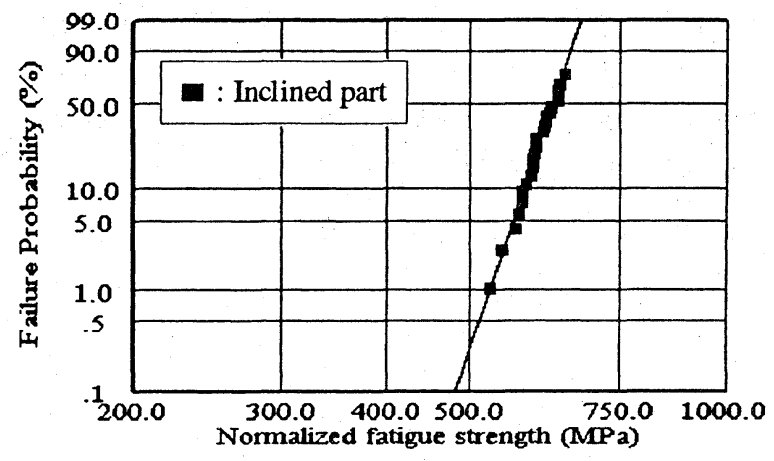

(b) Super high cycle fatigue region

Fig. 9. Distribution of normalized fatigue strength (S45C).
は存在しないと判定した。従って，超長寿命域において は Fig. 9 (b) に示すように傾斜部と水平部を分離せず分 布を評価している. 各領域におけるばらつきがワイブル 分布あるいは対数正規分布によりよく近似されているこ

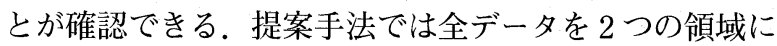
分離することにより，それぞれの領域において充分な適 合性をもった分布のあてはめが可能となることが分かる.

材料強度確率モデル研究会による高炭素ク口ム軸受鋼 $\mathrm{SUJ} 2$ の疲労試験結果 ${ }^{4)}$ について, 提案手法により分離 し得られた $S-N$ 線図と SEM 観察により 2 つ分布を分 離し，それぞれに対し最小二乗法で得られた $S-N$ 線図を 比較した例を Fig. 10 に示す. Fig. 10 において黒丸は表 面起点型破断，白丸は内部起点型破断による試験結果で ある。また，実線は提案手法により得られた $S-N$ 曲線で あり，破線は SEM 観察により分離し得られた $S-N$ 曲線 を示す。これらの比較から，本研究において提案した分 離アルゴリズムの妥当性が確認できる。特に，図中に示 す分離点が実験結果と対応していることが判る。なお， 超長寿命域において $S-N$ 曲線の傾きに差が見られるが， これは Fig. 10 中 A 点のデータを超長寿命域に属すると して $S-N$ 曲線を決定しているためであると考えられる。

機械構造用炭素鋼 S45C の焼き戻し材の疲労試験結果 における破壊確率 $1 \%$ および $0.1 \%$ に対する設計用 $S-N$ 線 図を Fig. 11 に示す.なお，信頼水準は 0.95 とした。得 られた結果は妥当であると考える。

同様にSUJ2 の疲労試験結果に対する破壞確率 $1 \%$ 扩よ

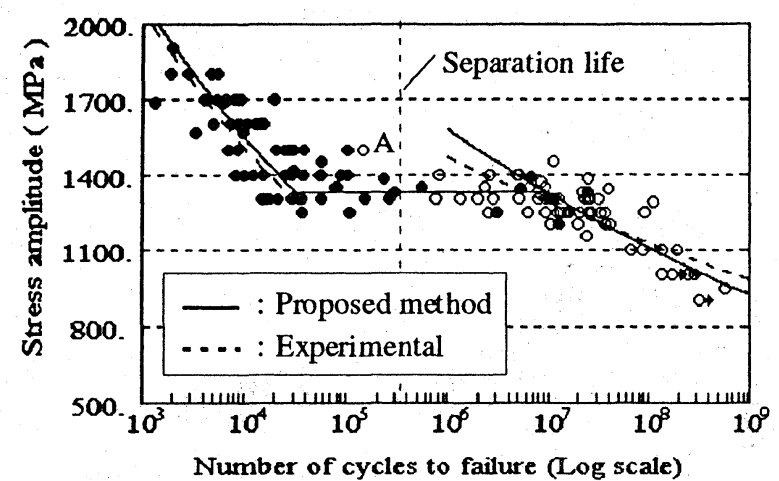

Fig. 10. Comparison of $S$ - $N$ curve for SUJ2.

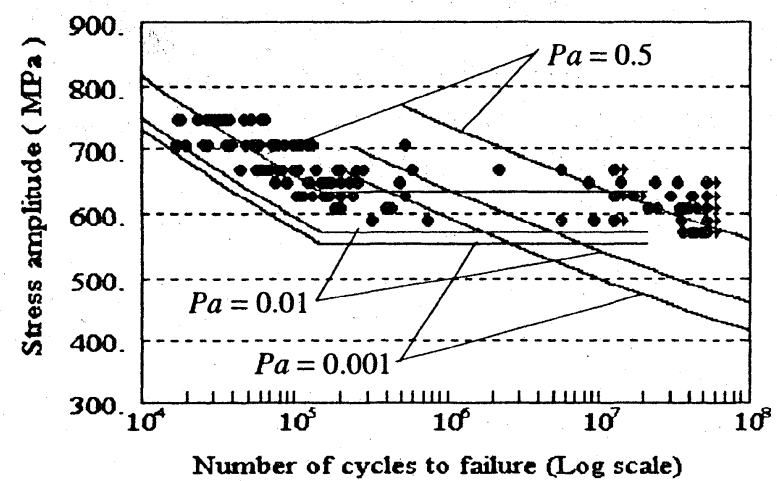

Fig. 11. Numerical result of $S-N$ curve with design margins for S45C (MSDRD : 0070200. MTL). 
び $0.1 \%$ に対する設計用 $S-N$ 線図を Fig. 12 に示す。ま た，比較のため，分離を行なわず決定した設計用 $S-N$ 線 図を Fig. 13 に示す. Fig. 12 と比較し, 特に水平部にお いて $S-N$ 曲線のシフト量が大きいことが確認できる. これらの結果から，各破壊モード每に分離することによ り，より合理的な設計基準が得られていることが確認で きる。

Fig. 14 は SUJ2 の疲労試験結果について, 各領域にお ける破壊確率と疲労強度の安全率の関係を示したもので ある. Fig. 14 より，長寿命域と超長寿命域においてば らつきが異なることが確認できる。従って，設計におい ては同一の材料を用いた場合でも，信頼性を考慮して安 全率を決定する場合は，想定される破壊モードに応じて 安全率を変化させる必要があることが分かる。

\section{6 結}

言

超長寿命域における疲労試験結果の評価法について提 案した。本研究ではこれらの領域において見られる $S-N$

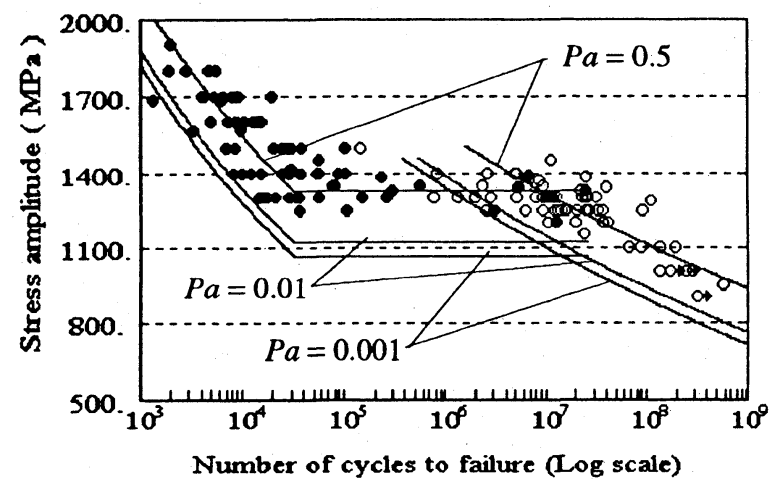

Fig. 12. Numerical result of $S-N$ curve with design margins for SUJ2.

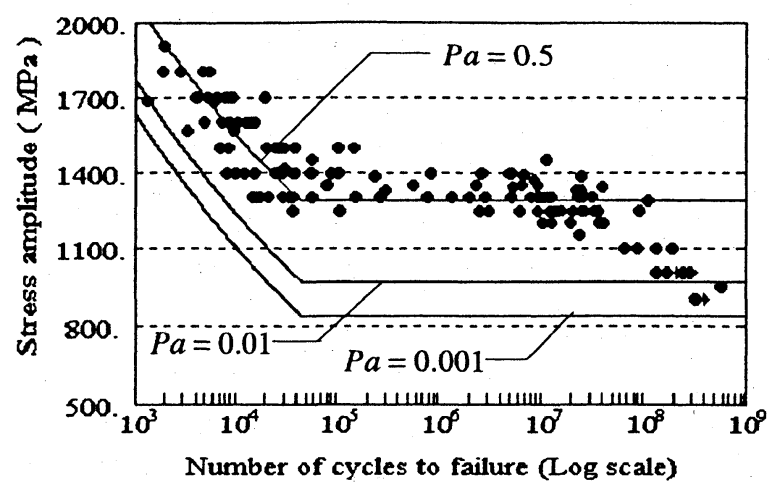

Fig. 13. Numerical result of $S-N$ curve with design margins for SUJ2 without separation.

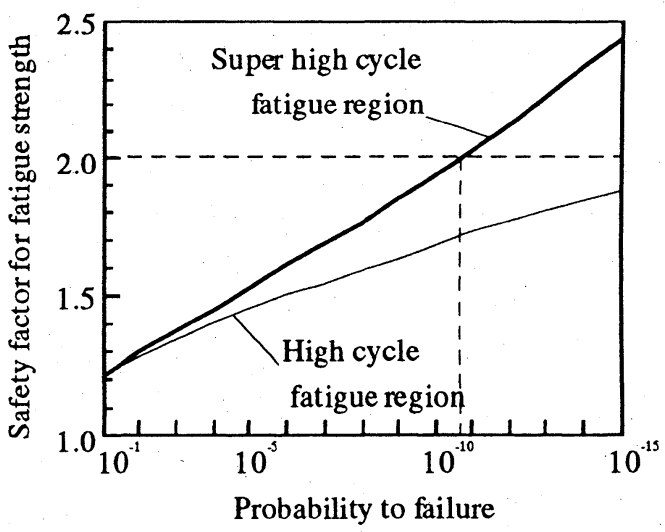

Fig. 14. Relation between probability to failure and safety factor for fatigue strength (SUJ2).

線図の 2 段折れ曲がり現象が表面起点型と内部破断起点 型破断による試験片が混在することに起因するものであ るという考えに基づき, 試験結果の分離および評価法を 提案した. 提案手法を実疲労試験データに適用した結果, 得られた結論は以下の通りである。

（1） SEM 観察結果等により破壊モードが確認できな い場合でも，疲労強度のばらつきに対し分布をあてはめ る際の適合度をもとに長寿命域と超長寿命域に分離する ことが可能である。

（2）全データを長寿命域と超長寿命域に分離し，それ ぞれの領域に打いて $S-N$ 曲線打よび疲労強度分布を決定 することにより，分離しない場合と比較して十分な当て はめ性を有する $S-N$ 曲線を決定することが可能であり， また合理的な設計用 $S-N$ 線図が決定可能である。

なお，本研究に対し助言を賜った立命館大学酒井達雄 教授に対しここに深く謝意を表する。

\section{参 考 文 献}

1) 座古 勝, 市川昌弘, 花木 聡, 材料, 47, 90 (1998).

2) 越智保雄, 日本材料学会第 48 期学術講演会講演論文集, 1, (1999).

3) 岡田憲司, 西川 出, 酒井達雄, 久世佳弘, 西岛 敏, 菅田 淳, 日本機械学会論文集, A-64, 249 (1998).

4) 材料強度確率モデル研究会, 日本材料学会第 48 期学術講 演会講演論文集，26（1999）。

5）材料強度確率モデル研究会編，“材料強度の統計的性質”, p.33（1992）養賢堂.

6）座古 勝, 市川昌弘，福吉 寬，材料， 44，546（1995）。

7) 酒井達雄，日本機械学会講演論文集，No.940-27，100 (1994). 